\title{
MRE11 Gene
}

National Cancer Institute

\section{Source}

National Cancer Institute. MRE11 Gene. NCI Thesaurus. Code C98167.

This gene plays a role in DNA recombination and repair. 